\title{
Capitalizing Rational Myths A Neo-Institutionalist Reading of Organization's Social Campaign Visuals
}

\author{
W. Guillaume Zhao \\ Lakehead University \\ Huihui Zhang \\ Lakehead University
}

Taking a neo-institutionalist lens, this paper examines how organizations visualize societal rational myths in a bid to lend legitimacy to their social claims. Specifically, by unraveling the semiotic features of an organization's visual communication, this research unpacks how rational myths at the societal level take on a physical, visual form in social campaigns. This study contributes to neo-institutionalism in organization studies by elucidating how less tangible aspects of institutions incarnate in visual forms in organizations' social undertakings, and by reconciling structural approaches of neo-institutional theory with more agentic ones.

\section{INTRODUCTION}

The immense literatures of neo-institutional theory, arguably one of the most dominant theories in organization studies and in contemporary social sciences, hold as the core tenet of this theory that organizations conform to institutional prescriptions and postulates in order to acquire legitimacy (DiMaggio \& Powell, 1983; Powell \& DiMaggio, 1991). A cornerstone construct connected to this "topdown" view of institution is "rational myths", or the shared meanings and understandings associated with social structures (Meyer \& Rowan, 1977; Zilber, 2006) which constitute the institutional context in which organizations operate, shaping actions and decisions of actors over time (Lammers \& Barbour, 2006; Meyer \& Rowan, 1977; Zilber, 2006).

However, as the emphasis of institutional research gradually shifted towards that on agency in the last two decades, as evidenced by the streams of research labeled respectively as institutional entrepreneurship (Battilana \& Leca, 2009; Hardy \& Maguire, 2008), neo-institutional strategies (Oliver, 2007) and institutional work (Lawrence \& Suddaby, 2006; Lawrence, Suddaby, \& Leca, 2009), the welcomed expansion of theoretical scope has often been accompanied by the trivialization of the original concept of rational myths. As Suddaby (2010) points out, the ideational focus on rational myths has largely disappeared from institutional theory.

This is regrettable, as the conceptualization of rational myths has afforded neo-institutional theory a departure from rational calculation or functional necessity (Meyer \& Rowan, 1977) to the socially constructed nature of organizational phenomena around institutions (Meyer, 2006). We argue that the emphasis of institutional influences is not incompatible with the essential role played by the human actor 
in the construction of reality. In a bid to reconcile the structural and agentic approaches of institutional theory and thereby fill this important theoretical lacuna, this study seeks to shed light on how rational myths find their ways in organization's agentic endeavors.

Organizations, from social movement to for profit corporations, engage in struggles in the discursive spaces (Gamson \& Modigliani, 1989; Hardy \& Phillips, 1999; Maguire \& Hardy, 2006; Phillips, Lawrence, \& Hardy, 2004; Schmidt, 2008). Meanwhile, the production of messages is viewed as central to institutional actions (Phillips et al., 2004). As actors strive to make sense of reality and gain legitimacy and material resources (Lawrence \& Suddaby, 2006), it is expected that they tap into societal level rational myths (Zilber, 2006). Yet, little is known on how organizations tap into the intangible ideational objects in their tangible activities. In other words, we still know very little about how organizations make the intangible more tangible. To add to our knowledge in this regard, this research asks,

How do rational myths become mobilized visually in organization' social campaigns? How does organization's visual translation of rational myths change with time?

To answer these questions, this study revisits the 2012 Québec Maple spring movement, the "largest act of civil disobedience in Canadian history" (Schonbek, 2012), focusing on the campaigns of organizations advocating institutional changes in the higher education sector. Given the visual nature of our research object, we methodologically draw on Peirce's semiotic perspective (Peirce, 1958, 1991) to unpack the visual semiotic dimensions of our data, comprising both the meaning dimension, i.e. themes of rational myths encapsulated in visuals, and their attribute dimension, i.e. semiotic categories and color codes of said visuals (Zhao, 2017). This, in turn, allows us to unpack how actors translate specific rational myths both in terms of the message meaning and visual attributes, as well as how such capitalization of rational myths evolve over time.

This research makes contributions to neo-institutional theory and organization theory in general in a few meaningful ways.

First, our focus on rational myths encapsulated in social campaign visuals allows us to showcase the compatibility between structural approaches of neo-institutional theory with more agentic approaches. Organizations and the individuals are suspended in a web of values, norms, rules, beliefs, and taken-forgranted assumptions (Barley \& Tolbert, 1997). While rules for actors are relatively transparent to follow, rational myths, which are implicit assumptions about appropriateness of actions which govern the way actors work, are hard to observe. This research, in this regard, provides some pioneering insights on how rational myths can be capitalized by actors' making the intangible tangible.

Second, this study adds to our existing debates around translation (Zilber, 2006) or the travelling of ideational objects. Specifically, this study fine-tunes our knowledge on how templates and "best practices" adapt in local contexts after having been imported. By unpacking the visual dimensions of societal rational myths, we demonstrate specific attributes of translation outcomes, after ideational objects have travelled vertically, i.e. from macro-societal level to micro-artifact level.

Related to the previous contribution, by examining the particularities of visual translation from the perspective of Peircean semiotics, this research answers the recent dual calls in management for accounting for the role of visuality in the organization setting (Bell \& Davison, 2013; Meyer, Höllerer, Jancsary, \& van Leeuwen, 2013), and thereby adds to the momentum of the on-going "visual turn" in our field.

\section{THEORETICAL ORIENTATIONS}

\section{Rational Myths and Translation}

Meaning is central to institutions (Zilber, 2002, 2006), which are often understood as "social constructions constituted through discourse" (Phillips et al., 2004). Typically, actors seeking legitimacy 
would make sense of reality, and endeavor to embed their messages in dominant discourses, which then produce institutions (Phillips et al., 2004).

The translation metaphor has been developed to depict the transformations of ideational and material objects in the process of their movement and adoption. Research has illuminated on such travelling within organizational boundaries and across national borders (Michal, 2005). Zilber (2006) provides even greater insights into the relationship between translation and rational myths, which often manifest themselves as societal myths (Zilber, 2008), institutionalized practices (Czarniawska \& Joerges, 1996), organizational forms (Meyer \& Rowan, 1977), and documents the travelling of ideas from the broad cultural environment to specific, industry-related institutionalized myths.

While recent research in organization studies has begun to probe into the symbolic and cultural processes around institutional myths (Hollerer, Jancsary, Meyer, \& Vettori, 2013; Zilber, 2006), direct examination of rational myths and their mobilizations have been scare. With the vast majority of organizational studies primarily focusing on texts, even less is known on how rational myths can be translated visually. This absence, while regrettable, is arguably due to the complexity of visuals, i.e. containing numerous interrelated component and multiple levels of meaning and thus creating almost indefinite interpretation possibilities for many readers (Scott, 1994).

Furthermore, as many art creators make extensive references to pre-existing knowledge about cultural myths (Johar, Holbrook, \& Stern, 2001), the abundance of myths related artifacts and the scarcity of academic insights on visual translation of ideational objects make visuals produced by organizations an ideal terrain for studying rational myths being mobilized in specific local spheres. To better account for said organizational visuals empirically, we now turn our attention to Charles Peirce's brand of semiotics for building a general analytical framework.

\section{Moving towards Visuals: Peircean Semiotics}

Language may lead to social change (Fairclough, Cortese, \& Ardizzone, 2007), thus making discursive activity highly political (Hardy \& Phillips, 1999). As multiple and often contradictory meanings exist in a discursive space (Hardy, 2001), struggles over meaning abound (Gamson \& Modigliani, 1989; Maguire \& Hardy, 2006; Phillips et al., 2004; Schmidt, 2008). So far, studies have generated important insights on how actors make use of texts and other forms of verbal language in their activities in the discursive space.

Recently there has been a rising awareness of the significance of visuals in social sciences, an awareness perhaps best captured by the term "pictorial turn" (Mitchell, 1996). Visuality is an important area of analysis, particularly for scholars working with meanings bundled in visually intensive messages. While texts are an important carrier of meaning, we will be remiss to regard messages as the exclusive domain of verbal language (Sebeok, 1991). Compared with verbal language, visuals are not as arbitrary and conventional as text. While texts are highly conventionalized, whose reading is taught through an extensive educational program, visuals are often more iconographic, and their interpretation are more "wired in" than arbitrary (Sebeok, 1991). Furthermore, visuals are capable of carrying complex meanings to broader audience while consuming rather low amount of space and time. Its ability to "invoke" without having to provide an argument makes it a powerful rhetorical tool (Meyer et al., 2013).

Since the works of Ferdinand de Saussure and Charles S. Pierce, semiotics has spawned various approaches that interpret messages in terms of their signs and patterns of symbolism (Sebeok, 1976). Fundamentally concerned with meanings, semiotics is applied in such fields as anthropology, cognition, communication, linguistics, and marketing.

A sign is anything that can be interpreted as standing for having a meaning for something other than itself, for instance an object or concept (Eco, 1984). This "standing for" is a relationship where meaning is created through both encoding and decoding by humans. Saussure developed a theory of signs centering on the signifier, e.g., a sound, expression, or image, and the signified, i.e. the concept for which it stands (Fiske, 1990).

Peirce's conceptualization of sign is featured by his triadic model consisting of object, representamen, and interpretant. A representamen represents the denoted object (comparable with Saussure's "signifier"). 
An object can be immediate, i.e. the object as represented in the sign, or dynamic, i.e. the object as it really is, on which the immediate object is based. An interpretant is the ramification of a sign as formed into a further sign by interpreting decoding the sign. It may be immediate, i.e. having the quality of the impression which a sign is fit to produce ("the meaning of sign" in everyday speech), dynamic, i.e. the actual effect of the sign on a mind, or final, i.e. having the effect which the sign would have on the mind if permitted by circumstances ("the purpose of sign").

Peirce's semiotic approach not only provides a richer context for understanding how visuals convey meaning than Saussure's signified-signifier dyad, but also boasts a systematic categorization of semiotic categories in signs: icon, index, and symbol (Peirce, 1958). An iconic sign resembles its object (e.g., a picture of house) and has in itself a certain character that the object possesses, thus allowing the icon to be interpreted as a signal even if the object does not exist. An indexical sign is one that denotes its object by virtue of a real connection or relation between them (e.g., dark clouds in the west are an index of impending rain). A symbol is a sign that denotes its object only by virtue of custom, a more or less systematic set of associations ensure that their interpretation (e.g., the meaning of the Statue of Liberty is determined by convention and is based upon agreement and learned through experience).

Previous research has connected signs to wider systems of meaning that are characterized as "referent systems ", "mythologies" (Rose, 2007), which, from a neo-institutionalist lens, capture the essence of rational myths. The Peircean semiotic approach is therefore ideal for the study of visual translation as signs. As most signs operate on several levels, we pay attention to a hierarchy of meaning in addition to categories of meaning in our methodology, to which we now turn our attention.

\section{METHODS}

\section{Empirical Setting}

We explore our research questions by investigating into the mobilization visuals of a combative organization in Québec during the 2012 Québec Maple Spring. To help contextualize the visual translation in question, it is important to briefly review the process of 2012 movement and the dynamic history of higher education in Québec.

The increase of higher education tuition and cutting of financial supports for higher education have become a recurring source of debate in Québec in recent decades. During the Quiet Revolution in 1960s, the then newly founded Ministry of Education of Québec set annual tuition at public universities at a low rate to ensure access. Fees were frozen for around two decades before it began to undergo a serious of freezing and unfreezing. In 2011, when the then provincial government in the same year reaffirmed in its budgets a decision to unfreeze tuition, it encountered unprecedented resistance chiefly led by such major student coalitions. The resistance expanded soon to a pan-province movement commonly called Maple spring, and in the end brought to power a new minority government, which cancelled of the tuition increase.

\section{Data Sources}

To understand how rational myths are translated, we compared two meaning systems: societal institutionalized myths in Québec at large and the visual "incarnation" of these rational myths in communication materials disseminated during said student movement. We compared these two meaning systems over a period of eleven months (November 2011 - September 2012). This specific observation window was selected in order to include all important events in the development of the movement.

In exploring societal rational d myths in Québec, we relied on the integration of existing cultural and political studies of Québec (Dufour, 1989; Gagnon, 1994, 2003) and looked for content pertaining to the taken-for-granted beliefs in the society. To assess the visual incarnation of rational myths, we conducted semiotic analysis on posters disseminated for mobilization purposes by the information committee of the focal organization during our window observation. Posters for other purposes such as activist training are screened out from our dataset, rendering a sample of 17 posters in total. 
To reduce observer bias, we prolonged our engagement in the field, and maintained contacts with key actors in the field, and collected books containing key actors' critical reflection on the movement (e.g., Nadeau-Dubois, 2013). We consulted newspaper reports of the same period, which, we believe, constitute reasonable proxy for the "discursive context" for these posters when they were displayed. This information also provides us some references on the emotional context associated with the depicted situation.

\section{Analytical Process}

As main objective of this study is to uncover how rational myths incarnate in visual forms, we followed Peirce's perspective, and conducted semiotic analysis on poster data, and move iteratively between the data, the emerging themes and existing theories to understand the phenomenon.

Visual and textual analyses differ in their interpretive logics. While most purely text-based analysis rely induction and deduction as platforms for reasoning, visual analysis relies more on "statistical inference", i.e. hypothesis testing or educated guessing, in relation to representamen and interpretant (Peirce, 1991). In addition, since most signs operate on iconic, symbolic and/or indexical level, our visual semiotic analysis addresses a hierarchy of meaning functions in addition to their categories. Given the fact that visuals in our study embedded minimal title-like texts, it might be expected that the complex sign system in the posters serves primarily two functions, an appeal to participate, either directly made or implied, as well as instructions on how to participate.

\section{Stage 1: Sensing the Data}

We first constructed chronology of key milestones in the student movement and of the posters (c.f. Figure 1 and Table 1). Before focusing on specific elements, we conducted a preliminary evaluation of individual posters. Overall, the posters convey one of the two messages: 1) movement claims such as free education and abolition of Bill 78, or An Act to Enable Students to Receive Instruction from the Postsecondary Institutions They Attend, which aimed to restrict protest and picketing near or on the premises of universities in Québec; or 2) mobilization information such as dates and location. This round of investigating also prompted us to notice elements that are most "telling" and visually powerful from the viewer's perspective, since not all elements in a message can be taken as communicated with equal force (Forceville, 2002). We categorized every piece of non-sentential meaningful information as visual, and sentential information as verbal. 
FIGURE 1

\section{COUNTS OF POSTERS FOR MOBILIZATION PURPOSES}

\section{Posters for Mobilization Per Month}

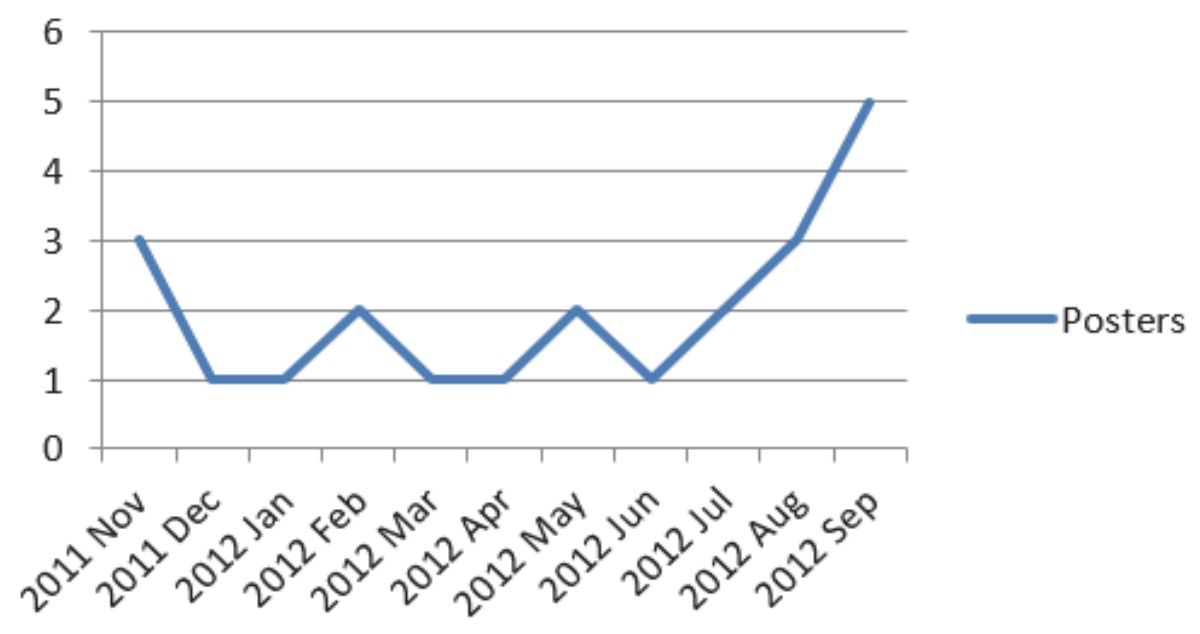

TABLE 1

KEY EVENTS IN 2012 MOVEMENT

\section{Time \\ Later 2011 \\ Early 2012}

Since 22 March

Since 18 May

Since 1 August

Since 5 September

\section{Major Events}

Forming movement coalition

Initial mobilization

Requesting to meet with the education authority

Mobilizing for the general "strike"

General strike in both colleges and universities in Québec starts

Mobilizing for continued general strike

Organizing the event on the day of the ninth anniversary of the

election of Liberal Party of Québec

Nightly protests resume after a brief "truce"

Negotiation and signing the agreement in principle

The coalition rejecting the agreement

Students setting up picket line around the establishments

Mobilizing for "civil disobedience"

Large scale protests occur across Québec

Organizing several events across the province.

Expansion of "casserole nights" against Bill 78 protests to most neighborhoods

Election campaigns since the dissolving of National assembly

Change of provincial government following election

Cancelation of tuition fee announced

Major students federations announcing the end of the strike

One student federation calling for continued mobilization for free education 


\section{Stage 2: Generating Representamen}

Signs, according to Peirce, creates in the mind both representamen, - an equivalent sign, or perhaps a more developed sign - , and interpretant, - the sign that first sign creates -, or a subsequent thought to which the sign gives rise (Peirce, 1991). In revealing the representamen, we deconstructed each poster, referring to its explicit content and denoted meaning (Tomaselli, 1996). Essentially, this step entails asking questions such as what the signs are and how they are presented.

\section{Stage 3: Generating Interpretant}

An interpretant exists at a more abstract, metaphorical level, and closely relates to the dominant values associated with a sign in a specific cultural context. Factors impacting the emergence and shape of interpretant include stylistic elements, such as metaphors, choices of words, etc. and more material elements, such color, lighting, and other special effects (Tomaselli, 1996). Deciding what interpretant could arise from posters was the most interpretative part of our analysis, and was carried out in several rounds.

Although the search for meaning is theoretically infinite, this interpretation is governed by the assumption that the creator tries to be optimally relevant to the audience, and is crucially constrained by the genre convention that the most effective posters use visual signs that are simple, eye-catching and direct, and a mobilization poster seeks to provide succinct information on the event, issue, and claim, and is not supposed to be read intensively. Our access to some protocol posters which the organization used as templates for their information material created also afforded us a better idea of visual creators' habitual formations or dispositions (Philipps, 2012). Specifically, we used the following criteria:

a. A referential relation can be created between a representamen and at least an interpretant.

b. The representamen and interpretant do not share the same level of abstractness.

\section{Stage 4: Clustering Meanings According to Themes and Patterns}

The objective of this step was to analyze the substances and patterns of meaning within and across individual posters, with the guidance of results from the previous two steps. We grouped various signs in the posters over time into themes of meaning, and identified semiotic categories i.e., iconic, symbolic or indexical, and the hue in which they were presented, respectively. Once these themes were stabilized and patterns and colors verified, we compared all themes with societal rational myths that we identified from Québec studies, documenting the semiotic dimensions of visual translation over time.

\section{FINDINGS}

\section{Rational Myths at Societal Level}

In order to explore how resisters translate rational myths through visual means, we first identified dominant societal Québécois rational myths. Cultural and political studies devoting to Québec and French Canada (Behiels, 1985; Behiels \& Hayday, 2011; Dufour, 1989; Gagnon, 1994, 2003) pointed us to three societal rational myths in the Québec's public discourse: Religious-Colonial, Secular-National, Collective-Universalistic. Table 2 summarizes these three rational myths. Note that only the dominant themes are listed here. In institutional environments exist competing meaning systems (Friedland \& Alford, 1991; Marquis \& Lounsbury, 2007; Purdy \& Gray, 2009; Thornton \& Ocasio, 1999). Indeed, this list does not include less frequent rational myths candidates, some of which are potentially in conflicts with the dominant ones. 
TABLE 2

SOCIETAL LEVEL RATIONAL MYTHS

\begin{tabular}{|l|l|l|l|}
\hline & Religious-Colonial & Secular-National & Collective-Universalistic \\
\hline $\begin{array}{l}\text { The continuation } \\
\text { of French } \\
\text { Canada and } \\
\text { Québec is a } \\
\text { result of }\end{array}$ & $\begin{array}{l}\text { Cultural and } \\
\text { linguistic protection } \\
\text { offered by the } \\
\text { Catholic church } \\
\text { against English } \\
\text { dominance }\end{array}$ & $\begin{array}{l}\text { The struggle of the } \\
\text { French-Canadian } \\
\text { majority in positions } \\
\text { of economic and } \\
\text { social inferiority }\end{array}$ & $\begin{array}{l}\text { Various organized } \\
\text { movements } \\
\text { (e.g.,sovereignism, } \\
\text { monolingualism, } \\
\text { feminism and labor } \\
\text { movement) }\end{array}$ \\
\hline Agent & Catholic church & $\begin{array}{l}\text { Francophone } \\
\text { population }\end{array}$ & Collective actors \\
\hline $\begin{array}{l}\text { Relevance } \\
\text { context }\end{array}$ & "English Conquest" & "Quiet Revolution" & "Globalization" \\
\hline Time frame & Prior to 1950s & $\begin{array}{l}\text { Between 1950s to } \\
1970 \text { s }\end{array}$ & $\begin{array}{l}\text { From 1980s to the turn of } \\
\text { the century and onwards }\end{array}$ \\
\hline Space & British Empire & North America & $\begin{array}{l}\text { Crossroad of North } \\
\text { America and Western } \\
\text { Europe }\end{array}$ \\
\hline $\begin{array}{l}\text { Dominant } \\
\text { discourse }\end{array}$ & $\begin{array}{l}\text { Antistatism and } \\
\text { Dominance }\end{array}$ & $\begin{array}{l}\text { Secularism, } \\
\text { Modernization, } \\
\text { Welfarism }\end{array}$ & $\begin{array}{l}\text { Equality, Prosperity, and } \\
\text { Democracy }\end{array}$ \\
\hline
\end{tabular}

The Religious-Colonial rational myth depicts the survival of Québec as part of world colonial history, where French-Canadians, albeit the majority in their province, were largely kept in positions of economic and social inferiority. The only institution which offered any kind of cultural and linguistic protection was the Catholic Church. Nonetheless, the fact that Church had gained its position of prominence in this province was also due to its encouraging the continuation of the traditional rural and agricultural lifestyle.

The Secular-National rational myth emphasizes the struggle of Francophone majority seeking to master their own destiny in political and social arenas. The confrontation between clergy and laity, and the various reforms in social policies, education, health and economic development is understood as Québec becoming a modern state.

The Collective-Universalistic rational myth depicts Québec as a stakeholder beyond the boundaries of the North America. The advancement of the society is understood in terms of various social struggles, and thus depicts Québec as joining the rest of democratic world in their fight for universal equality, justice and prosperity.

What is unique among the rational myths, and indeed, throughout Québec history, is the associated with social-political resistance and struggle. Once a "prince-ridden province", now strikingly secular (Zubrzycki, 2013). Once dominated by Anglophones, now legally monolingual francophone. This context presents us with a unique case to study translations around rational myths.

\section{Visual Translation of Rational Myths}

In this section, we discuss the ways in which rational myths are translated across our corpus of posters. For an analysis of the intricacies of the semiotic meanings, a different type of compilation than text-based analysis needs be created based on various visual elements. In other words, for each element, any information that can describe and explain meaning needs to be compiled. The analyses were conducted in terms of the percentage each rational myth, semiotic category, or color takes up among its respective total. Following Peirce's conceptualization, we first established the most salient first level interpretant for each representamen we identified; we then continued the inference chain by deciding on 
second level interpretants on the basis of their first level counterparts. The chain ended when the higher level interpretant reached the same level of abstractness with the societal rational myths.

Table 3 summarizes salient rational myths as visualized in the posters, together with their semiotic categories and colors (including both main color and background color). Percentages are constructed on the basis of the number of mentions.

TABLE 3

RATIONAL MYTHS VISUALIZED

\begin{tabular}{|c|c|c|c|}
\hline $\begin{array}{l}\text { Rational myths } \\
\text { (Based on meaning) }\end{array}$ & $\begin{array}{l}\text { Frequency of } \\
\text { Reference }\end{array}$ & $\begin{array}{l}\text { Rational myths } \\
\text { (Based on semiotic } \\
\text { categories) }\end{array}$ & Frequency \\
\hline Solidarity & $64.29 \%$ & Iconic & $55.7 \%$ \\
\hline Québec Nationalism & $13.46 \%$ & Indexical & $29.5 \%$ \\
\hline Capitalism & $12.50 \%$ & Symbolic & $14.8 \%$ \\
\hline Colonialism & $8.93 \%$ & & \\
\hline Secularism & $3.57 \%$ & & \\
\hline $\begin{array}{l}\text { Rational myths } \\
\text { (Based on main } \\
\text { color) }\end{array}$ & Weight & $\begin{array}{l}\text { Rational myths } \\
\text { (Based on } \\
\text { background color) }\end{array}$ & Weight \\
\hline Red & $50 \%$ & White & $56.25 \%$ \\
\hline Black & $20 \%$ & Black & $25 \%$ \\
\hline White & $16.7 \%$ & Red & $6.25 \%$ \\
\hline Yellow & $6 \%$ & Grey & $6.25 \%$ \\
\hline Grey & $3 \%$ & Yellow & $6.25 \%$ \\
\hline Blue & $3 \%$ & & \\
\hline
\end{tabular}

\section{Rational Myths}

Our semiotic analysis reveals six rational myths that are associated with a total of 156 interpretants, i.e. Solidarity, Capitalism, Québec Nationalism, Colonialism, and Secularism. By far, the most commonly mobilized rational myth is Solidarity, while the least common one being Secularism. Solidarity is derived from signs resembling demonstrators, citizens from all age groups, and students. Allusion to previous successful social movements and prominent figures are pervasive. Capitalism is coded from signs referencing to cold concrete jungle and cash-value business that are mammoth-like and void of empathy. In posters, neighboring signs such as arrows and fingers pointing to these signs reveal that the ultimate goals were the abolition of capitalism. By contrast, the other themes are more society-specific. They are all associated revolutionary histories in Québec for social justice and equality.

\section{Semiotic Categories}

A variety of signs were embedded in the posters, each with different semiotic category. The most common semiotic category is icon, which resembles its object in real world. The least common semiotic category is symbol (Note that, the "red patch" in Figure 2 which was widely adopted at the time of the movement was the object of an iconic sign, and it would in a couple of years achieve a symbol status, representing student movement in contexts well beyond Québec). Signs sometimes carry different semiotic categories. Elements with high levels of symbolic meaning were referred to less frequently than other elements that were higher in iconic meanings, perhaps attesting to the power of explicitness to create real-life impression. 
FIGURE 2

THE “RED PATCH” AS A SIGN WITH CHANGING STATUS

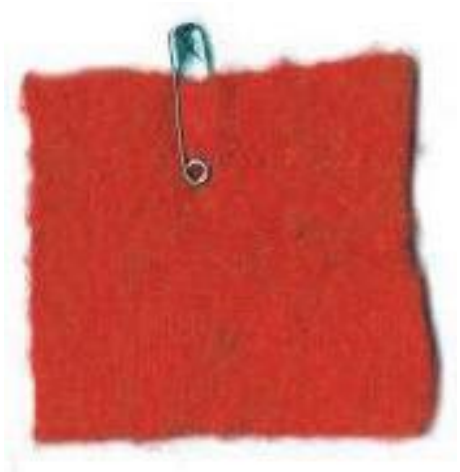

\section{Color Codes}

In these posters, the complex message about rational myths is being communicated through the translation of color codes. The language of the colors has two forms of existence - verbalized and nonverbalized. In this analysis, we focused on the non-verbalized color, such as the hues of visual sign and the background color. To identify the connotations of color code, we referred to a list of common kernel meanings at the color language derived from visual semiotic studies.

For representamen, the use of red is pervasive; $50 \%$ signs are in red, representing "anger", "flame", "heat", and "fiery". The frequent use of white, while possibly resulting from painting and printing convention especially when it is used in the background, may suggest "eternity", "world", and "severity". Black is dominant as both background and non-background color. It carries the meaning of "grave", "night", and "darkness".

\section{Visual Translation over Time}

In order to understand the visual translation of societal rational myths over time, we analyzed the respective prevalence of top three themes, all semiotic categories and top three non-background colors over time. Figures 3-5 present whether, and how, their prevalence changed over the years. When multiple posters exist for the same month, the mean for each item is taken.

\section{FIGURE 3}

\section{CHANGES IN VISUALIZED RATIONAL MYTHS OVER TIME}

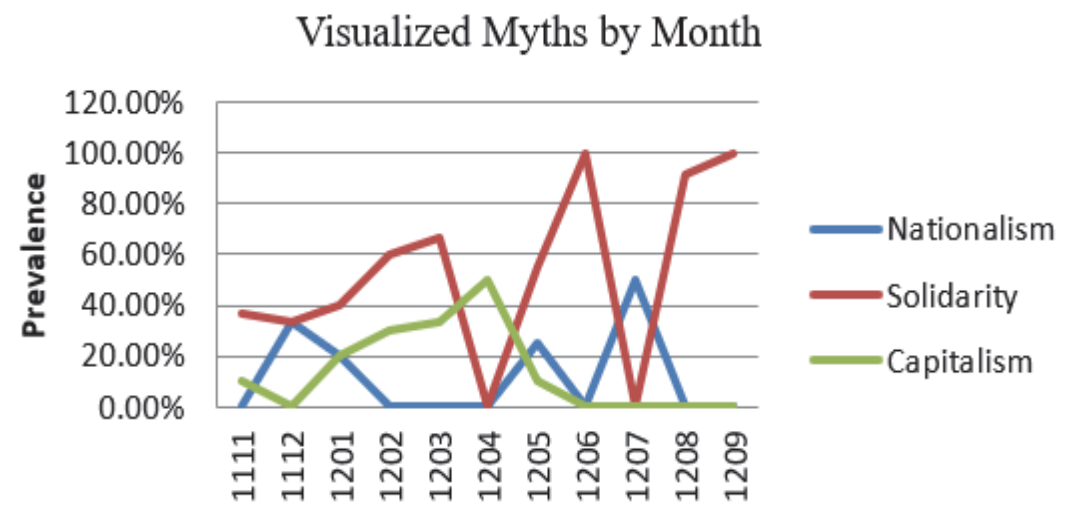




\section{FIGURE 4 \\ CHANGES IN SEMIOTIC CATEGORIES OVER TIME}

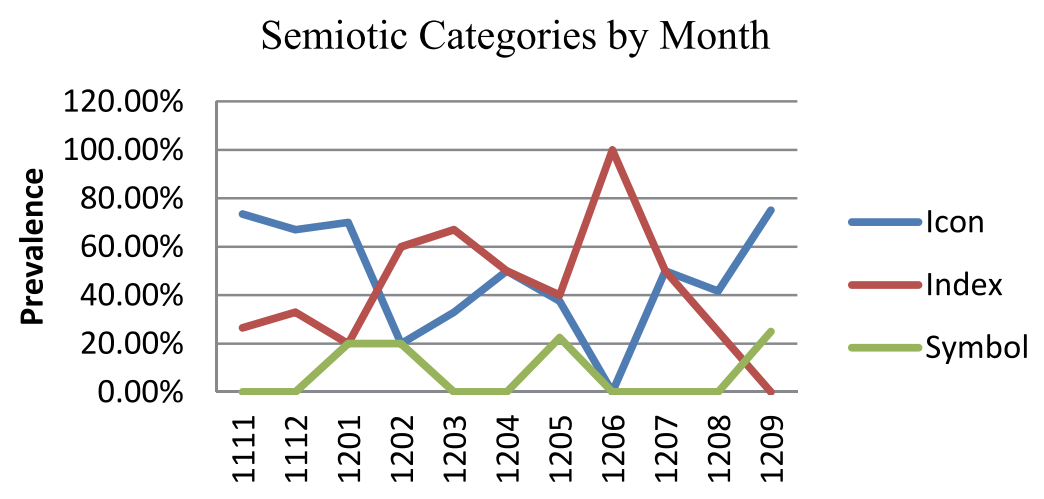

\section{FIGURE 5 \\ CHANGES IN DOMINANT COLORS OVER TIME}

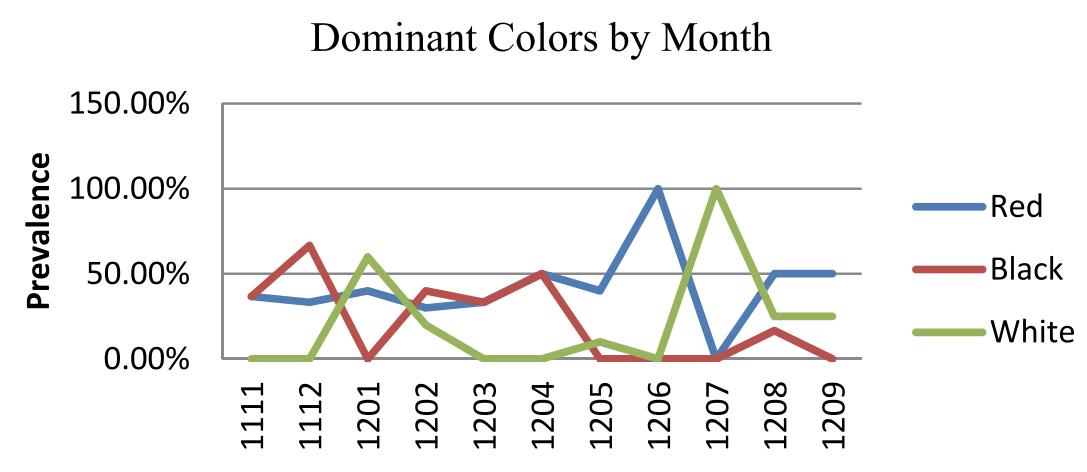

The prevalence of Québec Nationalism rational myth has undergone the smallest fluctuation, with the peak after the coming into force of Bill 78, which was widely regarded as a measure to restrict the freedom of demonstrations. By contrast, the rise and fall of the Solidarity curve seems to be closely related to the peaks of mass demonstrations for the cancellation of higher education tuition increase; March 2012 demonstrations witnessed the largest number of participants since the beginning of the movement; in May massive protests took place across the province under the theme "100 days of resistance"; in August and September, facing the prospect end of the movement, the movement coalition called for more solidarity in furthering the struggle until free education becomes a reality in the province. The rise and fall in the Capitalism rational myth is possibly linked to expansion of movement, and the coming into force of Bill 78, which presented a new target and rationale for mobilization.

The icon curve declined from a peak at the beginning of mobilization and rose back to the same level at the end of the movement. The change in indexical signs is striking, with its prevalence rising slightly above $20 \%$ to $100 \%$ in June 2012 and then shrank to 0 in September. The prevalence of symbolic signs changed very little, alternating between little use and non-use. Note that signs with different semiotic categories can create varied impact, and that the fluctuations also result from the blending of patterns.

The passing of Bill 78 seems to have affected the use of red the most. Following a slight increase since November 2011, this color received massive use in June 2012, and then fell back to its initial state after a jump. Equally considerable is the rise and fall of white color, two peaks seem to appear in comparably less eventual periods. Lastly, black was declining at a steady pace after few peaks before April 2012. 


\section{DISCUSSION AND CONCLUSION}

This study examines how societal level rational myths are translated by organizational actors in their social campaigns. Based on in-depth analysis of campaign visuals created and mobilized during the 2012 Québec Maple spring movement, this research unpacks how rational myths, as an intangible ideational object, incarnate visually in organization's communications, and also reveal the temporal dynamics of the visual translation of rational myths alongside the development of the campaign.

This research has a few important implications for neo-institutional theory and for organization theory in general. For starters, this research represents an early attempt to reconcile the more structural approaches to neo-institutional theory (Meyer \& Rowan, 1977; Thornton \& Ocasio, 1999)with those of a more agentic nature (Battilana, Leca, \& Boxenbaum, 2009; Lawrence \& Suddaby, 2006). Our analysis of visual communication materials reveals that rational myths can be and are capitalized in organization's social undertakings.

In neo-institutional theory, researchers have called for a fine-grained understanding of meanings and their local adaptations and transformations (Zilber, 2006). Research has shown that each culture contains meaning systems from which its members can borrow and recreate rational myths (Zilber, 2006), meanwhile, studies also demonstrated that the ability to offer theorizations for public consumption is political in nature and legitimacy-oriented (Maguire, Hardy, \& Lawrence, 2004). In our case, for organizational actors, such ability in the visual domain means taking visuals as semiotic resources. By providing a visual account of how rational myths travel across institutional spheres, this research refines our existing knowledge on how "culturally legitimated theorists" (Strang \& Meyer, 1993) adapt globally available theories and models for local situations (Greenwood, Suddaby, \& Hinings, 2002; Frenkel, 2005; Hardy \& Maguire, 2010; Maguire \& Hardy, 2009)

Second, in this analysis, we demonstrate the particularities of translation in the visual dimension. While many rational myths visualized at organizational level directly echo generic societal ones, e.g., Nationalism and Colonialism, some myths, e.g., (anti-)Capitalism and Solidarity appeared to have been reshaped, and some other myths simply do not in visualization, e.g., Religion.

Equally important, this research shows that the translation of rational myths by organizations is a dynamic process, involving the changes of semiotic elements. Within the translation stream of literature, research has yet to extensively examine the attributes in the artifacts which actors mobilize for their institutional and organizational goals and the changes in these attributes. This paper showcases that visuals are important materializer of meaning as pure texts, if not more so, and that attending to visuals affords us a more complete understanding of the dynamics of meanings in the institutional terrain.

Third, this research advances our understanding of meanings embodied in the visual practices by organizations. Taking multimodality seriously allows us to attend to the full range of messages, e.g., image, gesture, posture, etc, and the relationships between them (Jewitt, 2011). Yet, the difficulty of capturing visual meaning and the relatively lack of structured approaches to code and categorize such information lead to the under-theorization of questions that are of tremendous importance to students of meanings in organization studies. To inform the empirical studies on meanings in the visual dimension, this study developed a framework of visual meaning analysis with Peircean semiotics, and demonstrated how such a framework can be utilized to account for different attributes of visual meaning and the hierarchical functions of visuals. In this sense, this paper adds to the burgeoning intellectual movement across social sciences to incorporate visuals in the scope of inquiry (Meyer et al., 2013; Meyer, Jancsary, Höllerer, \& Boxenbaum, 2018). 


\section{REFERENCES}

Barley, S. R., \& Tolbert, P. S. (1997). Institutionalization and Structuration: Studying the Links between Action and Institution. Organization Studies, 18(1), 93-117.

Battilana, J., \& Leca, B. (2009). The Role of Resources in Institutional Entrepreneurship: Insights for an Approach to Strategic Management That Combines Agency and Institution. In L. A. Costanzo \& R. B. MacKay (Eds.), Handbook of Research on Strategy and Foresight (pp. 260-274). Edward Elgar Publishers. Battilana, J., Leca, B., \& Boxenbaum, E. (2009). How Actors Change Institutions: Towards a Theory of Institutional Entrepreneurship. The Academy of Management Annals, 3(1), 65-107.

Behiels, M. D. (1985). Prelude to Quebec's Quiet Revolution: Liberalism vs Neo-Nationalism, 1945-60. McGill-Queen's Press - MQUP.

Behiels, M. D., \& Hayday, M. (2011). Contemporary Quebec: Selected Readings and Commentaries. (M. D. Behiels \& M. Hayday, Eds.) (Vol. 30). McGill-Queen's Press - MQUP.

Bell, E., \& Davison, J. (2013). Visual management studies: Empirical and theoretical approaches. International Journal of Management Reviews, 15(2), 167-184.

DiMaggio, P. J., \& Powell, W. W. (1983). The Iron Cage: Institutional Isomorphism and Collective Rationality in Organizational Fields. Amercican Sociological Review, 48(2), 147-160.

Dufour, C. (1989). Le défi québécois: essai. L'Hexagone.

Eco, U. (1984). Semiotics and the Philosophy of Language. Indiana University Press.

Fairclough, N., Cortese, G., \& Ardizzone, P. (2007). Discourse and contemporary social change. (N. Fairclough, Ed.), Discourse (Vol. 54). Lang.

Fiske, J. (1990). Introduction To Communication Studies, Second edition. Routledge.

Forceville, C. (2002). Pictorial metaphor in advertising. Journal of Pragmatics (Vol. 31). Psychology Press.

Friedland, R., \& Alford, R. (1991). Briding society back in: Symbols, practices, and instittuional contradictions. In W. W. Powell \& P. J. DiMaggio (Eds.), The New institutionalism in organizational analysis (pp. 232-263). University of Chicago Press.

Gagnon, A.-G. (1994). Québec: État et Société, Tome 1. Québec Amerique.

Gagnon, A.-G. (2003). Québec: État et Société, Tome 2. Québec Amerique.

Gamson, W. A., \& Modigliani, A. (1989). Media discourse and public opinion on nuclear power: A constructionist approach. American Journal of Sociology, 95(1), 1-37.

Greenwood, R., Suddaby, R., \& Hinings, C. R. (2002). Theorizing change : the role of professional associations in the transformation of institutionalized fields. Academy of Management Journal, 45(1), 58-80.

Hardy, C. (2001). Researching Organizational Discourse. International Studies of Management \& Organization, 31(3), 25-47.

Hardy, C., \& Maguire, S. (2008). Institutional entrepreneurship. In R. Greenwood (Ed.), Organizational institutionalism (pp. 198-217). Sage.

Hardy, C., \& Maguire, S. (2010). Discourse, field-configuring events, and change in organizations and institutional fields: Narratives of DDT and the Stockholm convention. Academy of Management Journal, 53(6), 1365-1392.

Hardy, C., \& Phillips, N. (1999). No Joking Matter: Discursive Struggle in the Canadian Refugee System. Organization Studies.

Hollerer, M., Jancsary, D., Meyer, R., \& Vettori, O. (2013). Imageris of Corporate Social Responsiblity: Visual Recontextualization and Field-Level Meaning. Research in the Sociology of Organizations: Communities and Organizations, 39(2013), 139-174.

Jewitt, C., Kress, G., \& Mavers, D. E. (2009). The Routledge handbook of multimodal analysis. Routledge.

Johar, G. V., Holbrook, M. B., \& Stern, B. B. (2001). The Role of Myth in Creative Advertising Design : Theory, Process and Outcome. Journal of Advertising, 30(2), 1-25. 
Lammers, J. C., \& Barbour, J. B. (2006). An institutional theory of organizational communication. Communication Theory, 16(3), 356-377.

Lawrence, T. B., \& Suddaby, R. (2006a). Institutions and Institutional Work. In The SAGE Handbook of Organization Studies (p. 215).

Lawrence, T. B., Suddaby, R., \& Leca, B. (2009). Introduction: Theorizing and studying institutional work. In T. B. Lawrence, R. Suddaby, \& B. Leca (Eds.), Institutional Work: Actors and Agency in Institutional Studies of Organizations (pp. 1-27). Cambridge University Press.

Maguire, S., \& Hardy, C. (2006). The Emergence of New Global Institutions: A Discursive Perspective. Organization Studies, 27(1), 7-29.

Maguire, S., \& Hardy, C. (2009). Discourse and Deinstitutionalization: the Decline of Ddt. Academy of Management Journal, 52(1), 148-178.

Maguire, S., Hardy, C., \& Lawrence, T. B. (2004). Institutional entrepreneurship in emerging fields: HIV/AIDS treatment advocacy in Canada. Academy of Management Journal, 47(5), 657-679.

Marquis, C., \& Lounsbury, M. (2007). Vive la resistance: Competing logics and the consolidation of U.S. community banking. Academy of Management Journal.

Meyer, J. W., \& Rowan, B. (1977). Institutionalized Organizations: Formal Structure as Myth and Ceremony. American Journal of Sociology.

Meyer, R. E. (2006). Visiting Relatives: Current Developments in the New Sociology of Knowledge. Organization, 13(5), 725-738.

Meyer, R. E., Höllerer, M. a, Jancsary, D., \& van Leeuwen, T. (2013). The Visual Dimension in Organizing, Organization, and Organization Research: Core Ideas, Current Developments, and Promising Avenues. The Academy of Management Annals, 7(1), 489-555.

Meyer, R. E., Jancsary, D., Höllerer, M. A., \& Boxenbaum, E. (2018). The Role of Verbal and Visual Text in the Process of Institutionalization. Academy of Management Review, 43(3), 392-418.

Michal, F. (2005). The Politics of Translation: How State-Level Political Relations Affect the CrossNational Travel of Management Ideas. Organization, 12(2), 275-301.

Mitchell, W. J. T. (1996). Essays on Verbal and Visual Representation. University of Chicago Press.

Nadeau-Dubois, G. (2013). Tenir tête LUX ÉDITEU.

Oliver, C. (2007). Strategic Responses To Institutional Processes. Academy of Management Review, $16(1), 145-179$.

Peirce, C. S. (1958). Collected Papers of Charles Sanders Peirce. Havard University Press.

Peirce, C. S. (1991). Peirce on Signs: Writings on Semiotic UNC Press.

Philipps, A. (2012). Visual protest material as empirical data. Visual Communication, 11(1), 3-21.

Phillips, N., Lawrence, T. B., \& Hardy, C. (2004). Discourse and Institutions. Academy of Management Review, 29(4), 635-652.

Powell, W., \& DiMaggio, P. (1991). The New Institutionalism in Organizational Analysis. University of Chicago Press.

Purdy, J. M., \& Gray, B. (2009). Conflicting logics, mechanisms of diffusion, and multilevel dynamics in emerging institutional fields. Academy of Management Journal, 52(2), 355-380.

Rose, G. (2007). Visual methodologies: an introduction to the interpretation of visual materials. SAGE Publications.

Schmidt, V. a. (2008). Discursive Institutionalism: The Explanatory Power of Ideas and Discourse. Annual Review of Political Science, 11, 303-326.

Schonbek, A. (2012, September). The Long March: On the front lines with Quebec's student protesters. The Walrus, 15-16.

Scott, L. M. (1994). Images in Advertising: The Need for a Theory of Visual Rhetoric. Journal of Consumer Research.

Sebeok, T. A. (1991). A Sign is Just a Sign. Indiana University Press. 
Sebeok, T. A. \& Thomas A. (1976). Contributions to the doctrine of signs. University Press of America. Strang, D., \& Meyer, J. W. (1993). Institutional conditions for diffusion. Theory and Society.

Suddaby, R. (2010). Challenges for Institutional Theory. Journal of Management Inquiry, 19(1), 14-20. Thornton, P. H., \& Ocasio, W. (1999). Institutional Logics and the Historical Contingency of Power in Organizations: Executive Succession in the Higher Education Publishing Industry, 1958-1990. American Journal of Sociology, 105(3), 801-843.

Tomaselli, K. G. (1996). Appropriating Images: The Semiotics of Visual Representation (Interventi). Intervention Press.

Zhao, W. (2017). Protest in Style: Exploring Multimodal Concision in Rhetorical Artifacts. Research in the Sociology of Organizations, 54, 119-149.

Zilber, T. B. (2002). Institutionalization as an interplay between actions, meanings, and actors: The case of a rape crisis center in Israel. Academy of Management Journal, 45(1), 234-254.

Zilber, T. B. (2006). The work of the symbolic in institutional processes: Translations of rational myths in Israeli high tech. Academy of Management Journal, 49(2), 281-303.

Zilber, T. B. (2008). The work of meanings in institutional processes and thinking. In R. Greenwood, C. Oliver, K. Sahlin-Andersson, \& R. Suddaby (Eds.), Sage Handbook of Organizational Institutionalism (pp. 150-170). SAGE.

Zubrzycki, G. (2013). Negotiating Pluralism in Quebec: Identity, Religion, and Secularism in the Debate over "Reasonable Accommodation." In C. Bender, W. Cadge, P. Levitt, \& D. Smilde (Eds.), Religion on the Edge: De-centering and Re-centering the Sociology of Religion. Oxford University Press. 